and digital humanitarianism is a subject of dispute. The rapid increase in connectivity and commercial interest in connecting the world and the subsequent digitalization of education, relief, and humanitarian services, are exposed to critical reflection. Connectivity and open sharing of information generate security risks because it is not always possible to monitor those using the online information and for what purpose (Sandvik, Gabrielsen Jumbert, Karlsrud and Kaufmann 2014). Others claim that digital humanitarianism, remote management, and distant sensing help "to occlude the negative by headlining the problem-solving potential of technoscience" (Duffield 2016: 154). As technooptimists promote the new digital reality, others challenge the humanitarian adaptation of digital tools, and see them as a threat to true relief or development and as tools for surveillance and oppression (Duffield 2016). In between, there is a broad horizon for exploring the effects, risks, and possibilities of new technologies adapted to a humanitarian landscape.

\title{
Per Aarvik
}

\section{References}

Burns, R. (2014) Moments of Closure in the Knowledge Politics of Digital Humanitarianism. Geoforum, 53: 51-62.

Burns, R., Shanley, L. (2012) Connecting Grassroots to Government for Disaster Management. Woodrow Wilson Center Research Series.

Duffield, M. (2016) The Resilience of the Ruins: Towards a Critique of Digital Humanitarianism. Resilience, 4(3): 147-165.

Harvard Humanitarian Initiative (2011) Disaster Relief 2.o: The Future of Information Sharing in Humanitarian Emergencies. https://hhi.harvard.edu.

Meier, P. (2015) Digital Humanitarians. Routledge.

Sandvik, K.B., Gabrielsen Jumbert, M., Karlsrud, J., Kaufmann, M. (2014) Humanitarian Technology: A Critical Research Agenda. International Review of the Red Cross, 96(893): 219-242.

\section{Diplomacy}

Providing ongoing access to humanitarian aid during conflict and complex emergencies has always been a major concern for policy-makers and 
humanitarian actors. Thus, humanitarian negotiations have historically been conducted in situations of extreme insecurity and unstable political conditions to secure access, assistance, and protection for civilians (Mancini-Griffoli and Picot 2004; Pease 2016). The implicit, sometimes even hidden, practices of humanitarian negotiations (Magone, Neuman, and Weissman 2011) led to the concept of humanitarian diplomacy, which emerged in the early 2000s. Humanitarian diplomacy is generally defined as persuading decision-makers and opinion leaders to act at all times and in all circumstances in the interest of vulnerable people and with full respect for fundamental humanitarian principles. It encompasses activities carried out by humanitarian actors in order to obtain spaces from political and military authorities within which they can function with integrity. These activities include, for example, arranging for the presence of humanitarian organizations in a given country, negotiating access to civilian populations in need of assistance and protection, monitoring assistance programs, promoting respect for international law and norms, and engaging in advocacy at a variety of levels in support of humanitarian objectives (Minear and Smith 2007). In this scenario, humanitarian diplomacy is understood as a means to reach the most vulnerable people. Indeed, the commitment to "leave no one behind" has been a key feature of discussions about the Sustainable Development Goals, and there is now a growing political consensus that operationalizing "leave no one behind" is a crucial element of the 2030 Agenda (Transforming our World: The 2030 Agenda for Sustainable Development). However, a significant tension is embedded in humanitarian diplomacy. Diplomacy, for instance, is essentially about representation of one polity vis-à-vis another polity. Humanitarianism is about advocating for and helping people in need. Therefore, diplomacy is characterized by compromise and pragmatic dealings, whereas the public image of humanitarian action (which often contradicts what happens in practice) is the opposite: it is about working for ideals and universal principles regardless of the interests of specific political actors.

The variety of humanitarian actors involved in complex emergencies and their competing priorities and goals produce different understandings and practices of humanitarian diplomacy. Its definitions and perceived content vary as widely as the number of organizations (or states) using the term and the humanitarian operations that they carry out. There is a significant difference between conceiving the idea of humanitarian diplomacy, using the term itself, and arriving at international recognition for its definition and agreement on how it should be conducted (Régnier 2011).

As massive humanitarian crises, such as those in Bosnia, Afghanistan, Iraq, Yemen, and Syria, have shown, the protected areas that humanitarian action is 
meant to provide are increasingly the targets of parties within conflict. This leaves many people either trapped within the conflict or forced to flee along routes where they are in high risk of exploitation from trafficking, and where humanitarians have little or no access. The dangers that humanitarianism faces today are the result of war zones and prolonged crises where civilian populations are the intended victims, where access is difficult, where aid workers are in danger of being perceived as a threat or a kidnapping target, and where their own physical safety is in doubt (Barnett and Weiss 2008). Access to humanitarian aid is increasingly challenged in ways that also redefine the role of humanitarian actors and their diplomatic capacity. The character of violent conflicts is changing, and the politicization of access to aid has become an integral element of conflict itself (De Lauri 2018).

\section{Antonio De Lauri}

\section{References}

Barnett, M., Weiss, T.G., eds. (2008) Humanitarianism in Question: Politics, Power, Ethics. Cornell University.

De Lauri, A. (2018) Humanitarian Diplomacy: A New Research Agenda. см I Brief, 4.

Magone, C., Neuman, M., Weissman, F. (2011) Humanitarian Negotiations Revealed. The msf Experience. Hurst \& Co.

Mancini-Griffoli, T., Picot, A. (2004) Humanitarian Negotiation: A Handbook for Securing Access, Assistance and Protection for Civilians in Armed Conflicts. Centre for Humanitarian Dialogue.

Minear, L., Smith, H. (2007) Humanitarian Diplomacy: Practitioners and their Craft. United Nations Press.

Pease, K. (2016) Human Rights and Humanitarian Diplomacy. Manchester University Press.

Régnier, P. (2011) The Emerging Concept of Humanitarian Diplomacy. International Review of the Red Cross, 93(884): 1211-1237.

\section{Displacement}

Displacement can be induced by war, conflict, environmental disasters, and other natural and human-made hazards. The humanitarian response to forced 